\title{
Thesis in The Date of Tomb TT 254 Verification through Analysis of its Scenes
}

\author{
Sahar Mohamed Abd el-Rahman Ibrahim \\ Faculty of Archeology, Cairo University, Egypt
}

\begin{abstract}
This paper extrapolates and reaches an approximate date of the TOMB of TT 254, the tomb of Mosi (Amenmose) (TT254), has not been known to Egyptologists until year 1914, when it was taken up from modern occupants by the Antiquities Service, The tomb owner is Mosi 1 , the Scribe of the treasury and custodian of the estate of queen Tiye in the domain of Amun

This tomb forms with two other tombs (TT294-TT253) a common courtyard within Al-Khokha necropolis. Because the Titles/Posts of the owner of this tomb indicated he was in charge of the estate of Queen Tiye, no wonder a cartouche of this Queen were written among wall paintings. Evidently, this tomb's stylistic features of wall decorations are clearly influenced by the style of Amarna; such as the male figures with prominent stomachs, and elongated heads, these features refer that tomb TT254 has been finished just after the reign of Amenhotep IV (Akhenatun). Table stands between the deceased and Osiris which is divided into two parts: the first part (as a tray) is loading with offerings, then the other is a bearer which consisted of two stands shaped as pointed pyramids... based on the connotations: 1- Offerings tables. 2- Offerings Bearers. 3- Anubis. 4- Mourners. 5- Reclamation of land for cultivation. 6- Banquet in some noble men tombs at Thebes through New Kingdom era.
\end{abstract}

Applying some inductive analogies, conclude that This Theban tomb belongs to the era of King Ay.

Keywords: tomb, Mosi (Amenmose),scribe, treasury, custodian, queen Tiye, Amun, Al-Khokha necropolis, paintings, Amarna, stomachs, heads, Amenhotep IV (Akhenatun), pyramids, Thebes, King Ay.

$$
\begin{aligned}
& \text { المُلخص: تتعرض هذه الأطروحة لوضع تأريخ تقريبي لمقبرة TT254، وذلك ما كان مجهولًا حتى عام } \\
& \text { ع ا9 ا ـ تتسب المقبرة إلى موزي، كاتب الخزانة والراعي لممتلكات الملكة تيه في عصر آمون. } \\
& \text { تتكون هذه المقبرة مع مقبرتين أخريين (TT294-TT253) في فناء مشترك داخل مقبرة الخوخا، ويتضح } \\
& \text { أن سمات هذه المقبرة من ناحية زخارف الجدران قد تأثرت بشكل كبير بأسلوب العمارنة، فوجود مثل هذه } \\
& \text { الثخصيات الذكورية صاحبة المعى (البطون) البارزة، والرؤوس الطويلة نتير إلى أن المقبرة TT254 قد }
\end{aligned}
$$




$$
\begin{aligned}
& \text { اكتملت بعد فترة حكم أمنحتب الرابع (إخناتون). والمنضدة الموجودة بين المنوفى وأوزوريس والتي تتقسم } \\
& \text { إلى جزئين: الجزء الأول (كدرج) يتم تحميله بالقرابين، والجزء الآخر عبارة عن حامل يتكون من قائمين }
\end{aligned}
$$

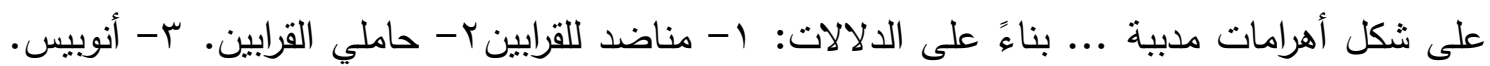

$$
\begin{aligned}
& \text { ع- المشيعين. 0- استصلاح الأراضي للزراعة. 7- مأدبة في بعض مقابر الرجال النبلاء في طيبة } \\
& \text { خلا عصر الدولة الحديثة. من خلال تطبيق بعض المقارنات والتحليلات وُجد أن مقبرة طيبة تتنمي إلى لـى } \\
& \text { عصر الملك آى. } \\
& \text { الكلمات الدالة: مقبرة، موزي (أمنيموس)، كاتب، خزانة، راعي، الملكة تيب، أمون، جبانة الخوخا، النقوش، } \\
& \text { العمارنة، المعى، الرؤوس، أمنحوتب الرابع، إخناتون، الأهرامات، طيبة، الملك آي. }
\end{aligned}
$$

\section{Preface:}

The objective of preparing and submitting this thesis is to:

Extrapolate and reach an approximate date of The TOMB of TT 254

\section{DATE OF THE TOMB OF TT 254 BY ANALYZING ITS SCENES}

The tomb of Mosi (Amenmose) (TT254), has not been known to Egyptologists until year 1914, when it was taken up from modern occupants by the Antiquities Service.

\section{The tomb owner:}

Mosi $\|^{4}$, the Scribe of the treasury and custodian of the estate of queen Tiye in the domain of Amun ${ }^{(1)}$.

\section{Previous work:}

Normande GarisDavies, hasworked first in tomb (TT254). He published only two of its scenes (Fig .1) $)^{(2)}$ andsome other scenes done using pencil tracingto

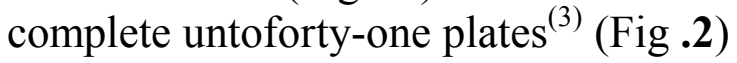

Although more Egyptologists have visited this tomb, only one photograph has been published. The one of some musicians. ${ }^{(4)}$

(1) BerthaPorter and Rosalind Moss. Topographical Bibliography of Ancient Egyptian Hieroglyphic Text, Reliefs, and Paintings. Vol.I, 1. The Theban Necropolis: Private Tombs (Oxford: 1960), 338;Nigel Strudwick, The Tombs of Amenhotep, Khnummose, and Amenmos at Thebes (Nrs. 294, 253, and 254) (=Griffith Institute Monographs, 1) (Oxford: Griffith Institute, 1996), 58-9.

(2) Norman de Garis Davies, "A Peculiar Form of New Kingdom Lamp", JEA, Vol. 10, No. 1 (Apr., 1924), fig. 6.

(3) http://www.griffith.ox.ac.uk/gri/4TT254.html (January 19, 2012).

(4) Lisa Manniche, Lost Tombs, A Study of Certain Eighteenth Dynasty Monuments in the Theban Necropolis (New York: 1988), 182. 
In 1984-1990, an expedition of Cambridge University in Khokha carried on what Norman and Nina de Grais Davies did before, then Nigel Strudwick and Helen M. Strudwick published this tomb. ${ }^{(1)}$

\section{Location of the tomb:}

This tomb forms with two other tombs (TT294-TT253) a common courtyard within Al-Khokha necropolis.

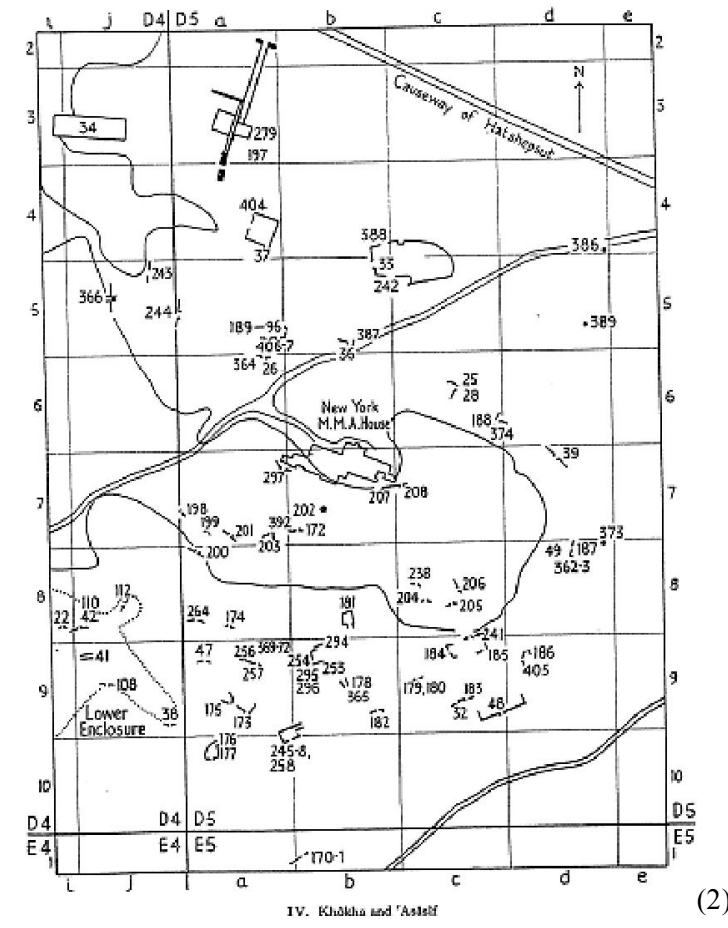

\section{Date of the Tomb:}

- Because the Titles/Posts of the owner of this tomb indicated he was in charge of the estate of Queen Tiye, no wondera cartouche of this Queen werewritten among wall paintings. ${ }^{(3)}$.(Fig.3)

- Evidently, this tomb's stylistic features of wall decorations are clearly influenced by the style of Amarna; such as the male figures with prominent stomachs, and elongated heads, these features refer that tomb TT254 has been finished just after the reign of Amenhotep IV (Akhenatun). ${ }^{(4)}$

Nigel Strudwick dated the tomb from the transition- to Ramesside period.

Inspite of the above efforts, the exact date of this tomb is still uncertain till now.

(1) Strudwick, op. cit., 58.

(2) PM., Vol. 1. , 499.

(3) Strudwick, op. cit., pl. XXXI

(4) Ibid., 59. 
Therefore, We have taken the following new methodology to come up with a specific date:

Examining motifs of scenes as depicted on the tombs' walls that pertained to the era of late part of the of $18^{\text {th }}$ Dynasty (from Amenophis III) and the beginning of the $19^{\text {th }}$ dynasty ( Seti $1^{\text {st }}$ ), which they are :

\begin{tabular}{|l|l|}
\hline King & Theban Tombs (TT) \\
\hline $\begin{array}{l}\text { Amenophis III to } \\
\text { Amenophis IV }\end{array}$ & TT 55,TT181,TT192,188,TT57,TT175,\&TT52 \\
\hline Ay & TT49 \\
\hline Horemhap & TT255,TT291\&51 \\
\hline Seti I & TT51,TT1\&TT323 \\
\hline
\end{tabular}

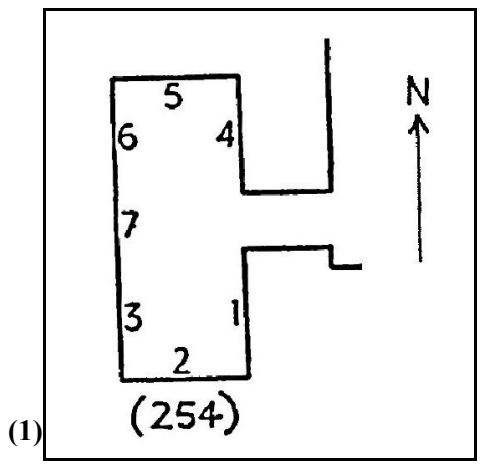

\section{Probative Evidences}

\section{The indications aboutoffering tables}

\begin{tabular}{|l|l|}
\hline Amenhotep III\& IV & $\begin{array}{l}\text { offering table took the shape of Ka- } \\
\text { sign , with two trays upon two } \\
\text { bearers (2) }\end{array}$ \\
\hline Ay(TT49) & $\begin{array}{l}\text { offering table has two trays upon two } \\
\text { bearers which have the pyramid shape }\end{array}$ \\
\hline Horemheb & Offering table has two bearers ${ }^{(3)}$ \\
\hline
\end{tabular}

(1) PM,Vol.1., 334.

(2) Manniche Lise. The Tomb of Manniche, Lise. "The Tomb of Nakht the Gardener, at Thebes", no. 161, as copied by Robert Hay, JEA 72 (1986), Fig.10 Nakht the Gardener, at Thebes, no. 161, as copied by Robert Hay. JEA 72(1986),Fig.10; Davies, Norman de Garis. The Tomb of the Two Sculptors at Thebes $(=T T S, \quad 4) . \quad$ (New York: 1925), pl.XXIX; http://www.osirisnet.net/tombes/nobles/ramose/e_ramose55_p.2,(C) Copyright OsirisNet 2008.2,(C) Copyright OsirisNet 2008.

(3) Baud, Marcelle, "Etienne Drioton. Tombes thébaines: Nécropole de Dirâ' Abû 'n-Nága, Le tombeau de Roy" MIFAO 57, 1 (Cairo: 1935), fig.13; Zahi Hawass, Life In Paradise, The Noble Tombs of Thebes, (American University Cairo Press: 2009), 85. 


\begin{tabular}{|l|l|}
\hline Seti $1^{\text {st }}$ & $\begin{array}{l}\text { Offering table took the shape of Ka- } \\
\text { sign } \boldsymbol{U} \text { with cornice edge, It has four } \\
\text { stands. A compound offering table has } \\
\text { bearer with top-edge taken crown } \\
\text { shape. }\end{array}$ \\
\hline
\end{tabular}

\section{Fig. 4: The context of the scene}

Table stands between the deceased and Osiris which is divided into two parts: the first part (as a tray) is loading with offerings, then the other is a bearer which consisted of two stands shaped as pointed pyramids.

that table is a compound one.

Fig. 5 Plate 1. (wall4): A comparison between the offering tables depicted on wall of tomb TT49 Aytime, and on the wall of TT 254, same features;both offering tableshaveone tray upon two stands, which of pyramid shape in the presence of Osiris.

\section{The Indications which provided above similar with the implications of the reign of $\mathrm{Ay}$}

\section{The indications about offering Bearers}

\begin{tabular}{|l|l|}
\hline $\begin{array}{l}\text { Amenhotep } \\
\text { III\& IV }\end{array}$ & $\begin{array}{l}\text { Male bearers have oval-shaped heads, in folded (Plissés) aprons. Their } \\
\text { details are accurate expressions. Some of them carry the Amon bunches } \\
\text { of Roses, others carry offering tables. (2) }\end{array}$ \\
\hline Ay & $\begin{array}{l}\text { Male bearers, some wear short frontal folded (Plissés) kilts, others wear } \\
\text { long ones. Some carry the bouquets of Amon, others carry offering } \\
\text { tables. The male figures with prominent stomachs, and elongated heads. }\end{array}$ \\
\hline Horemheb & $\begin{array}{l}\text { Male bearers in folded (Plissés) aprons. Carry the Amon bunches of } \\
\text { Roses. }{ }^{3}\end{array}$ \\
\hline Seti $1^{\text {st }}$ & $\begin{array}{l}\text { Male bearers wearing slippers, bald head. The male figures with } \\
\text { prominent stomach. Carry bouquets of Amon. }\end{array}$ \\
\hline
\end{tabular}

(1) Norman de Garis Davies, Two Ramesside Tombs at Thebes: The Tomb of Antefoker, Vizier of Sesostris I and of His Wife Senet (No. 60) (London: EES, 1920), pl. XII; Mohamed Saleh, Das Totenbuch in der Thebanischen Beamtengräbern des Neuen Reiches, Texte und Vignetten (Minze: 1984), Abb.8.

(2) HawassZahi, op. cit., 167, 216; Allam, M. Mahdi, Joseph Lindon Smith, The Man and the Artist (Cairo: 1949), plate no.1.

(3) WildHenri, La tombe de Néfer-hotep (I) et Neb-néfer à Deir el-Médîna (No.6) et autres documents les les concernant, MIFAO 103, Tome II (1979), Henri.

(4) Davies, N. de GaDavies, Norman. de Garis, op. cit., pl. XVI.1.XVI. 


\section{Fig. 6 (wall2.): The context of the scene:}

Males and femalesoffering bearers in two sets.

males: bald heads, bare feet, some in long and other in short kilts with Plissés, those former who carry a bouquet of Amun,the others carry the offering tables with both hands, which piled with offerings .

Females: wearing a long white robe with a wide collar in the shape of lotus. Placed on the long wigs with blue and green lotus flowers as bands on their forehead.

1st lady: carrying blue and green flower.

2nd: carrying a red vase contains four candles pointed shape with blue flame.

3rd \& 4th: carrying plate surrounded with flowers.

The Indications which provided above about offering bearers similar with the implications of the reign of $\mathrm{Ay}$

\section{The indications about Anubis supports Osiris}

\begin{tabular}{|l|l|}
\hline Amenhotep III & $\begin{array}{l}\text { Anubissits behind Osirisin full appearance: nude chest,wide } \\
\text { green collar, short white and yellow kilt. Has thick mouth.Holds } \\
\text { Ankh- sign in his left hand }\end{array}$ \\
\hline Tutankhamun & $\begin{array}{l}\text { Anubis sits opposite Osiris back to back in full appearance, with } \\
\text { tail ,holding Ankh sign in his left hand and scepter in his right } \\
\text { hand,wearing bracelet around one wrist. }\end{array}$ \\
\hline Ay & $\begin{array}{l}\text { Osiris supported by the goddess of the West. Anubissits } \\
\text { individually in full appearance, holding Ankh sign in his left } \\
\text { hand and scepter in his right hand. }\end{array}$ \\
\hline $\begin{array}{l}\text { Ramesses } \\
\text { Seti I }\end{array}$ & $\begin{array}{l}\text { I- } \\
\text { Anubisstandsbehind Osirisin full appearance, withtail. Anubis } \\
\text { supports Osiris's head by his left hand }\end{array}$ \\
\hline
\end{tabular}

(1) http://www.osirisnet.net/tombes/nobles/anonyme175/photo/anonyme175_bs_38893_detail_02. Jpg.

(2) http://www.osirisnet.net/tombes/nobles/houy40/photo/houy40_cd_6477.jpg;

(3) Davies, NDavies, Norman de Garis, op. cit. pl. IX; http://www.osirisnet.net/tombes/nobles/userhat51/photo/userhat51_mr_17.jpg. 


\section{Fig.7(wall5): The context of the scene:}

The deceased offered to the deity Osiris who issupported by both Anubis andgoddess of the West.

Numerology:

- Anubis Stands directly behind the Osiris'sthrone.

- Anubis appears as a humanslim body with jackalhead, and has long pointed nose.

- Wearing a short white and yellow kilt, holding anAnkh sign in his right hand.

\section{The goddess of West followed behind Anubis.}

The Indications about Anubis supports Osiris which provided above similar with the implications of the reign of Ay

\section{The indications about Mourners}

\begin{tabular}{|c|c|}
\hline $\begin{array}{l}\text { Amenhotep } \\
\text { III - IV }\end{array}$ & $\begin{array}{l}\text { The mourners Form in sets, standing in rows, accompanying their } \\
\text { children , putting the right hand on heads and left on legs ,they are } \\
\text { squatting }{ }^{(1)} \text {.Tears on their cheek depicted in varyshapes: sporadic - } \\
\text { wavy dashes or dots. } \\
\text { They depicted in different color of skin and all of them with flabby } \\
\text { breast. } \\
\text { They have Different hairstyles, Tied or untied. Putting on large long } \\
\text { robe in Plissés. }\end{array}$ \\
\hline Ay & $\begin{array}{l}\text { Male and female mourners whom are in diversity movements. While } \\
\text { some females are gathering dust from earth to put upon heads, and } \\
\text { another placing the right hands on the heads and left on the ground } \\
\text { where they are squatting, the others are lifting their hands in front of } \\
\text { their faces or hands tied up at the chest. } \\
\text { Females putting wide long gowns with short sleeves in Plissés. }\end{array}$ \\
\hline Horemheb & $\begin{array}{l}\text { Female mourners similar in movements they are kneeling and placing } \\
\text { their right hands on the heads. There are tears dropping on cheeks. They } \\
\text { are putting on long white dresses in Plissés with a node directly down } \\
\text { the ladies nude breast. }\end{array}$ \\
\hline
\end{tabular}

(1) Abeer El-Shahawy, The Funerary Art of Ancient Egypt(American University Cairo Press: 2005), fig. 32, 63; Nina de Garis Davies, Scenes from Some Theban Tombs (Nrs. 38, 66, 162, with Excerpts from81)(= Private Tombs at Thebes, 4).(Oxford: Griffith Institute, 1963), pl. XIX;Davies Norman de Garis. The Tomb of the TwoSculptors, pl. XXIV, pl. XXVI; K. Wilkinson, Charles, "Egyptian Wall Paintings, The Metropolitan Museum's Collection of Facsimiles", MMA (New York: 1979), pl. 29.

(2) http://www.segweb.ch/hari2/RH 02 2 09.jpg;

http://www.osirisnet.net/tombes/nobles/roy/photo/roy 15.jpg; Baud, Marcel and Etienne Drioton, "Le tombeau de Panehsy In: Georges Foucart, et al. Tombes thébaines: Nécropole de Dirâ' Abû'n-Naga: Le tombeau de Rö̈ (tombeau no. 255); Le tombeau de Panehsy (tombeau no. 16); Le tombeau 


\section{Fig.8,9,10(wall2): The context of the scene:}

Female mourners lined up in six rows:

-Two of them in the first three rows.

-The first three rows are longer than their peers, perhaps they are ones of the deceased ladies.

- All female mourners wearing long dresses with large short folded sleeves, and all of them put on longblack hair wigs.

- They are lifting their hands in front of their faces asgrief.

- Tears on their cheeks depicted indots.

The Indications about Mourners,

Which provided above similar with the implications of the reign of Ay

\section{The indications about Reclamation of land for cultivation}

\begin{tabular}{|l|l|}
\hline $\begin{array}{l}\text { Amenhotep } \\
\text { III }\end{array}$ & $\begin{array}{l}\text { The meandering land has somelakes. Farmers are using axes and shovels for the } \\
\text { land Reclamation }\end{array}$ \\
\hline Ay & $\begin{array}{l}\text { Workers in lands to refine papyrus marshes, to cut off papyrus stalks and } \\
\text { uprooting trees. There is supervision man who standing and holding an } \\
\text { illustrative map of the whole project to guide the workers. Some workers are } \\
\text { bald which mean they are foreign, while others have features of Amarna. } \\
\text { All of them put on kilts with folds. }\end{array}$ \\
\hline Ramses II & $\begin{array}{l}\text { workers do the reclamation of lands as uprooting of trees by using ropes \& } \\
\text { axes }^{(2)}\end{array}$ \\
\hline
\end{tabular}

Fig.11(wall 1): The context of the scene: The scene is somehow similar to the wilderness of the land and exploited for agriculture

The far right of the scene is an acacia tree (perhaps within the jungles) and cutting off by man with hand axe and pressed onto his right foot on the trunk of the tree to balance it.

- A trunk seems like bending backwards.

d'Amonmos (tombeau no. 19 ); Le tombeau d'Amon-am-anit" (tombeau no. 277) (= MIFAO, 57, 2).

(Cairo: 1928-1935), fig. 8.

(1) Nabil Zaki Marwan, Egyptian Agricultural Life in the New Kingdom (PhD Theses, Cairo University Department of Egyptology: 1989), Fig.39.

(2) Abdel-Qader, M. Mohammed, "Two Theban Tombs: Kyky and Bak-en-Amun" ASAE 59 (Cairo: 1966): Pl. XLII; Baud, Marcel and Etienne Drioton. op. cit., Fig.23. 
- This man is wearing a short kilt for ease of movement, another man wearing a kilt length up until after the knee with long folds, holding a shovel perhaps to remove foliage that rises over his head.

Numerology:

- Workers uprooting trees from the jungles.

- Workers are bald.

- Workers putting on kilts with folds, which its length up the knee.

- Workers have features of Amarna.

The Indications which provided above similar with the implications of the reign of Ay

VI. The indications about Banquet

\begin{tabular}{|c|c|}
\hline Amenhotep III & $\begin{array}{l}\text { Male guests are in Transparent shirt with one } \\
\text { shoulder, folded kilts, wide necklace and } \\
\text { ointment cone on their heads. }\end{array}$ \\
\hline Amenhotep III \&IV & $\begin{array}{l}\text { Male guests wearing long shirt with half sleeve } \\
\text { and short kilts in Plissés with, open wrapped } \\
\text { cloak in two colors yellow and white, putting } \\
\text { wide necklace, bracelets. } \\
\text { They catch cloth in hands \& stick with sign shmm } \\
\text { ointments cones on their heads. }\end{array}$ \\
\hline Ay & $\begin{array}{l}\text { Male guests wearing shirts with wide Plissés } \\
\text { sleeves up to the elbow and folded Plissés kilts } \\
\text { which cover from its behind with a triangular } \\
\text { shape cloth of the forward,and put wide collar } \\
\text { around the neck }\end{array}$ \\
\hline Ramses II & $\begin{array}{l}\text { Bald male guests, putting ointment cones on their } \\
\text { heads. Wearing loose Cloaks, which are colored } \\
\text { fabric in Plissés, and long transparent kilts, other } \\
\text { short ones beneath. They design translucent } \\
\text { white shawls on their shoulders. They put on } \\
\text { white sandals. } \\
\text { They hold sign and lotus with leaf of lettuce in } \\
\text { hands. }\end{array}$ \\
\hline
\end{tabular}

Fig.12(wall2): The context of the scenein TT 254

- The Banquet, Perhaps a harvest celebration(Feast) where there is Rennut the goddess seen in scene, this banquet including guests and relatives they sit on chairs without both arms and backs, the chairs have wooden supports under the bases.Plate2

Numerology:

- The scene begins from right where first guest holding pot by his hand which offered by butler. 
- Shaved heads male guests.

- They're wearing shirts with wide sleeves in Plissés its length until their elbows, and folded kilts which covered of triangular shape in its front.

- Guests wearing large necklaces around their necks.

Fig .13(wall 5): The context of the scene of Musician scene and clappers:

In the presence of the decease and his wife through the scene of offering by their daughter, the musical female band playing.

\begin{tabular}{|c|c|}
\hline Amenhotep III & $\begin{array}{l}\text { lyre-female player wearing a large transparent } \\
\text { cloak with one shoulder. } \\
\text { large harp- female player in large transparent robe } \\
\text { with half sleeves and the player of long neck lute } \\
\text { wearing a rectangular transparent cloak with belt. } \\
\text { There is a double flute-female player in that scene } \\
\text { All of them have the same hairstyles in big braids, } \\
\text { putting ointment cones on their heads with lotus } \\
\text { buds on both front and back of the heads . } \\
\text { Wearing large circle earrings. }{ }^{(1)}\end{array}$ \\
\hline $\begin{array}{c}\text { Amenhotep IV \& Tut ankh } \\
\text { Amon }\end{array}$ & $\begin{array}{l}\text { Tabors and drum female musicians with dancers } \\
\text { are wearing loose Cloak in Plissés with widely } \\
\text { Large-half sleeves and dropping large circular } \\
\text { earrings. }\end{array}$ \\
\hline Ay & $\begin{array}{l}\text { Musicians drum and Tabors, wearing loose Cloak } \\
\text { in Plissés with widely sleeves All of them have } \\
\text { the same hairstyles in big braids putting ointment } \\
\text { cones on their heads with lotus flower blooming } \\
\text { on their forehead. } \\
\text { There are young girls who knocking on their } \\
\text { bodies as rhythms. }\end{array}$ \\
\hline Ramses II & Priestess for Oboe Playing $^{(3)}$ \\
\hline
\end{tabular}

\section{This band is composed of:}

-A micro lyre female player, (harp with eight strings).

- A great harp female player (with twelve strings).

(1) Norman de Garis Davies, The Tomb of Nakht at Thebes (New York: MMA, 1917), pl. XV; Lise Manniche, The Erotic Oboe In Ancient Egypt, Third International Meeting of the ICTM Study Group on Music Archaeology, Verlag für systematische Musikwissenschaft GmbH Bonn, fig.2.ig.2.

(2) Davies, Norman de Garis, Tomb of the Two Sculptors, op. cit., pl.V.; http://www.osirisnet.net/tombes/nobles/kheru/photo/kherouef_oi_24. gif; Spencer, Patricia,"Dance in Ancient Egypt",NEA, Vol. 66, No. 3, (Sep., 2003)119.

(3) Manniche, Lise, op. cit., fig.3. 
- Flute female player.

- lute female Player (lute with a long neck).

- Little girl knocking on her body as a rhythm.

All of them are naked and putting long wigs stretched by headband (shenet), topped with fatty cones with lotus flower blooming on their forehead.

\section{- Numerology:}

- each Musician Bends her knee with rising the heel of her other leg and touching the ground by toes.

- Back whirling motion without giving any justification.

- Long stretched wigs by headbands (shenet).

- blooms of lotus are on their foreheads.

The Indications which provided above about Banquet(including the musicians and dancers) is similar with the implications of the reign of Ay

The conclusion

Based on the above summarized connotations: 1- Offerings tables. 2Offerings Bearers. 3- Anubis. 4- Mourners. 5- Reclamation of land for cultivation, and 6- Banquet in some noble men tombs at Thebes through New Kingdom era.

Applying some inductive analogies, Conclude that:

This Theban tomb belongs to the era of King Ay. 


\section{Illustrative Figures}

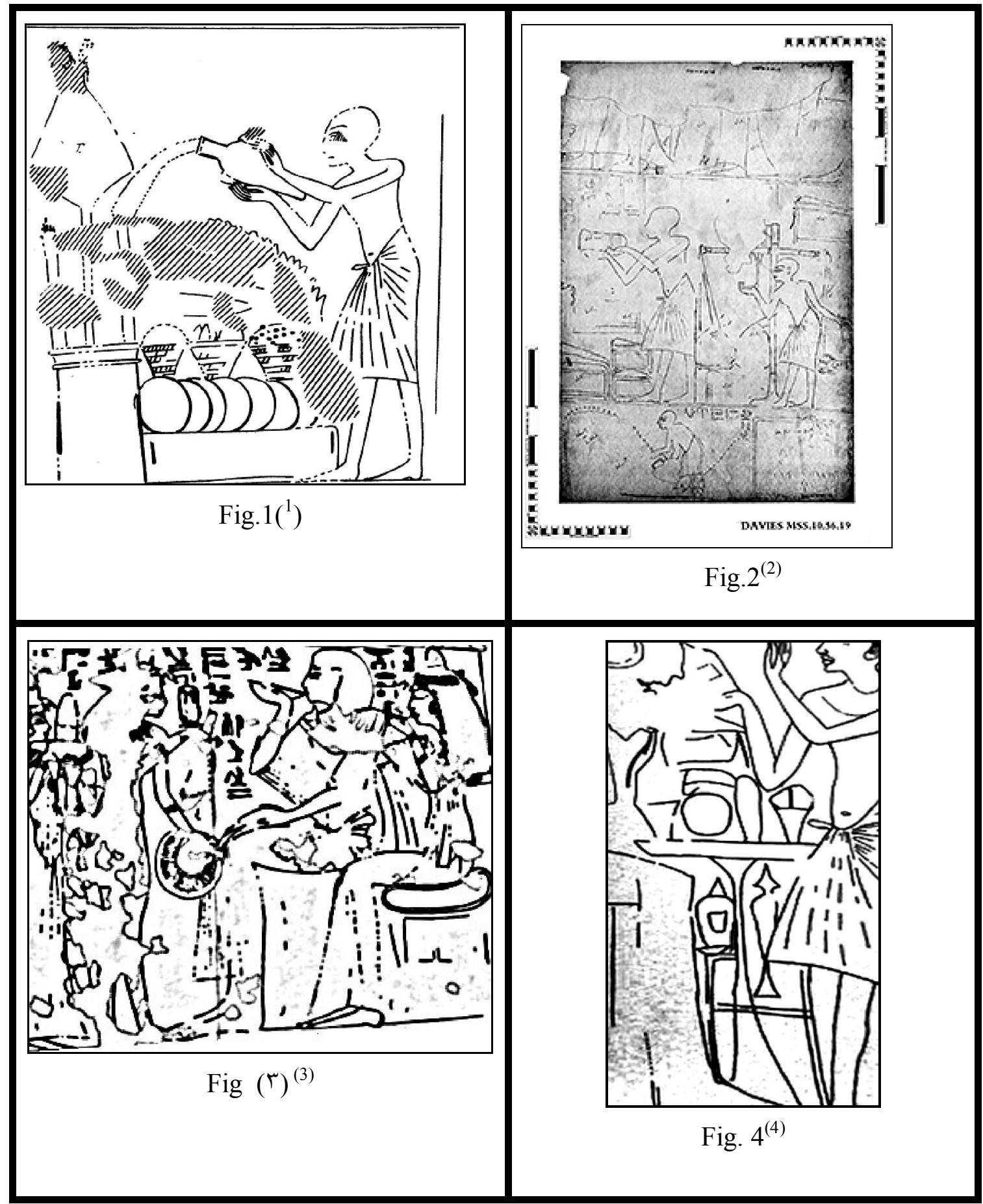

(1) Davies, Norman de Garis, A Peculiar, fig. 6.

(2)http://www.griffith.ox.ac.uk/gri/gif-files/Davies_10_56_19m.jpg.

(3) Strudwick, Nigel, The Tombs of Amenhotep, op. cit., P1. XXXI.

(4) Strudwick, op. cit., Pl. XXXIII scene 6.1.a. 


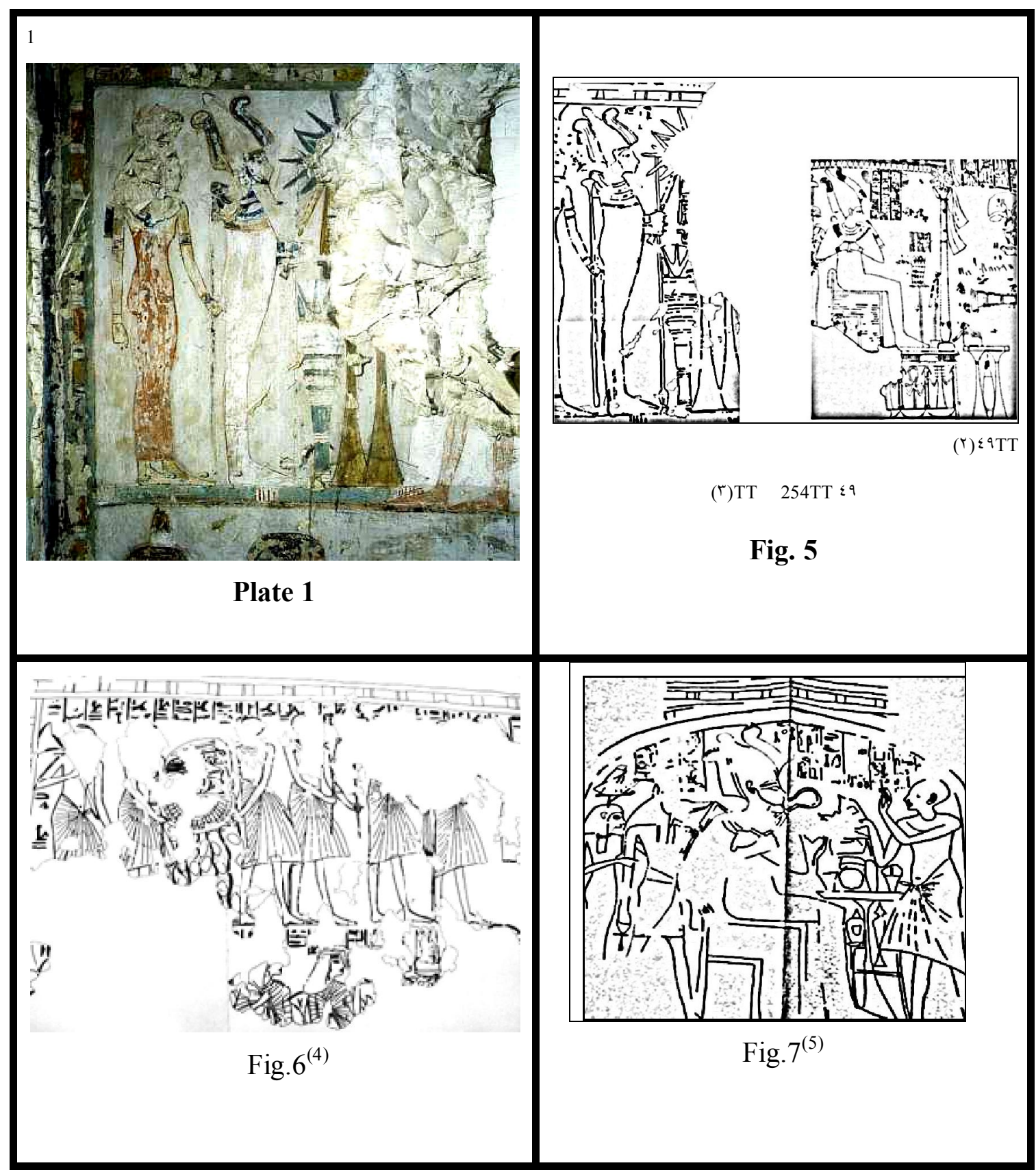

(1) Cambridge Theban Tombs Project,

(TT254), http://www.fitzmuseum.cam.ac.uk/tt99/tt254/,71L.jpeg.

(2) Norman de Garis Davies, The Tomb of Nefer-hotep at Thebes (New York: 1933), Pl. XIV.

(3) Nigel Strudwick, op. cit.,Pl. XXXV scene 6.1.a.

(4) Ibid., pl.XXIX sce.3.1.c.

(5) Ibid., pl. XXXIII. 

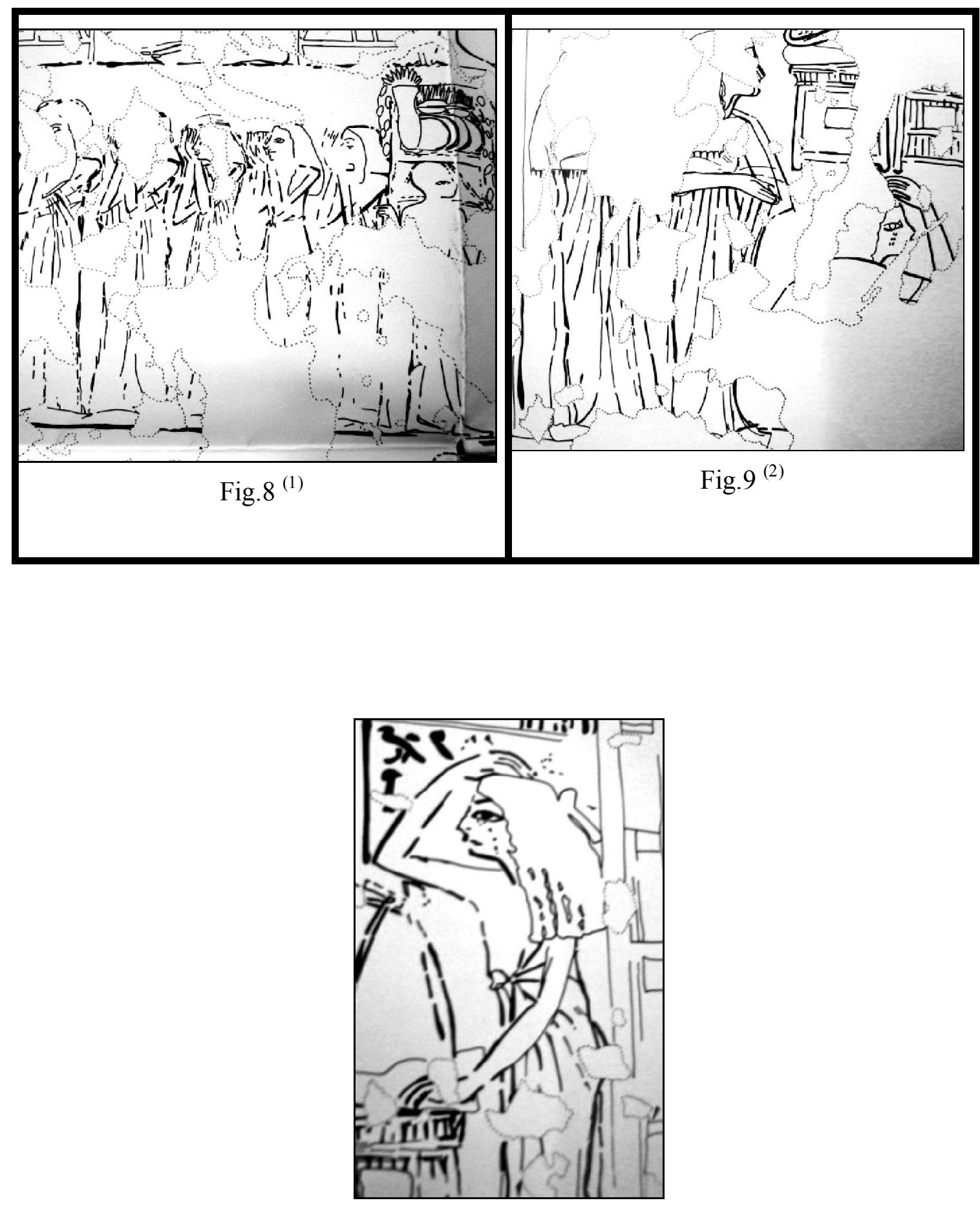

Fig. $10^{(3)}$

(1) Strudwick, Nigel. op. cit., pl. XXVIII, 2. 2. b.

(2) Ibid., pl. XXXII. scene 6. 4. a.

(3) Ibid., pl.8 a XXXIV. scene 6. 4. 6. 


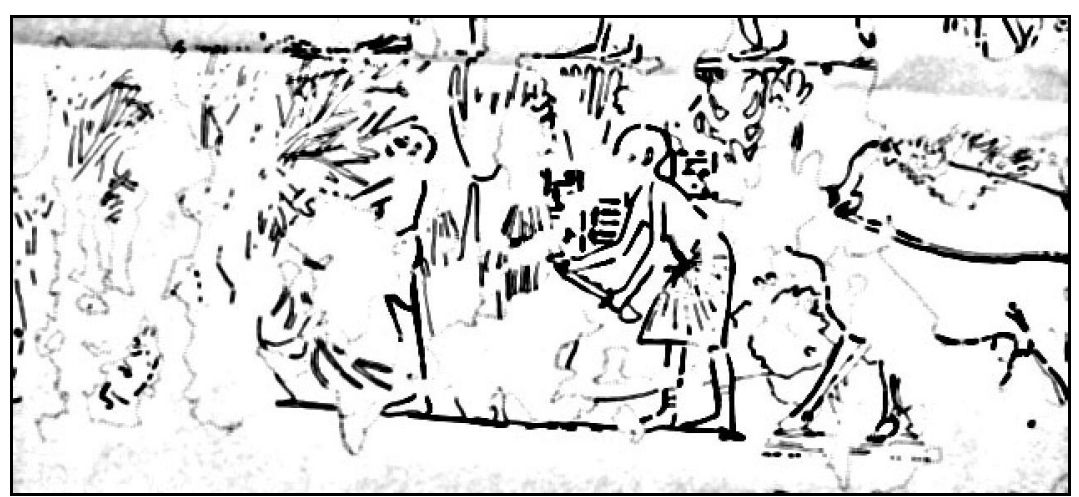

Fig. $11^{(1)}$

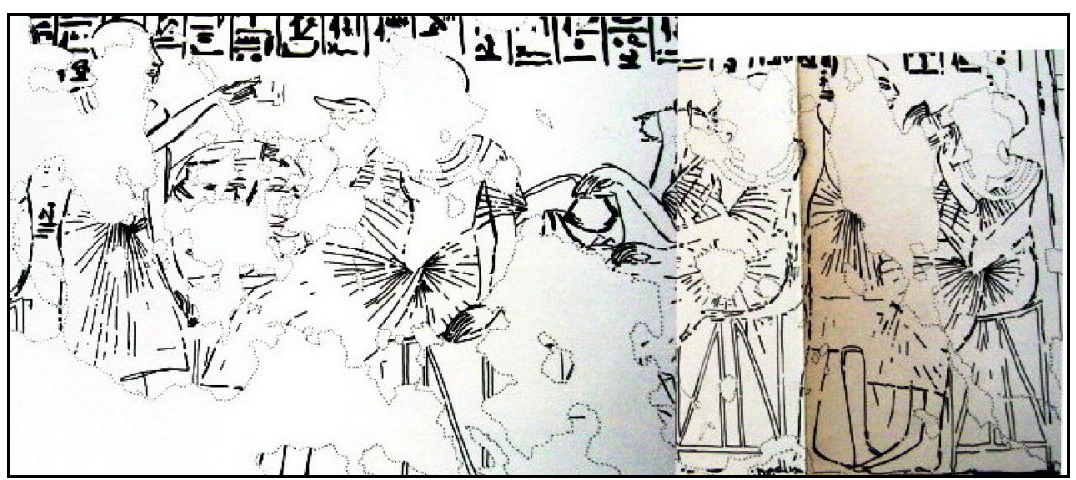

Fig.12

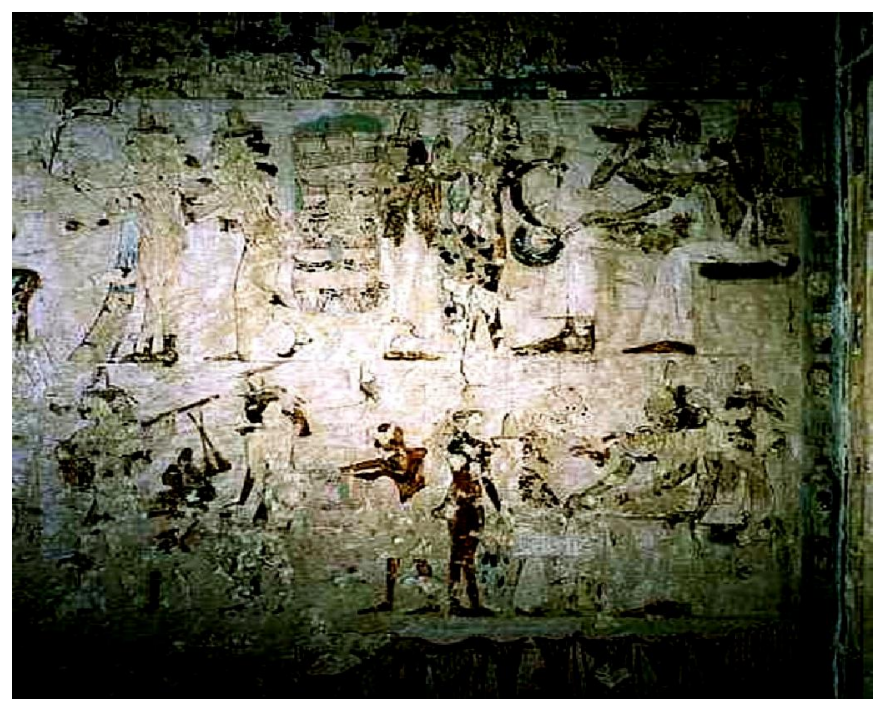

$\mathrm{P} 1.2^{(2)}$

(1) Ibid.,pl.XXVII,scene 1.2.c.

(2) Cambridge Theban Tombs Project, Tomb of Amenmose (TT254), http://www.fitzmuseum.cam.ac.uk/tt99/tt254/ 51R.jpeg 


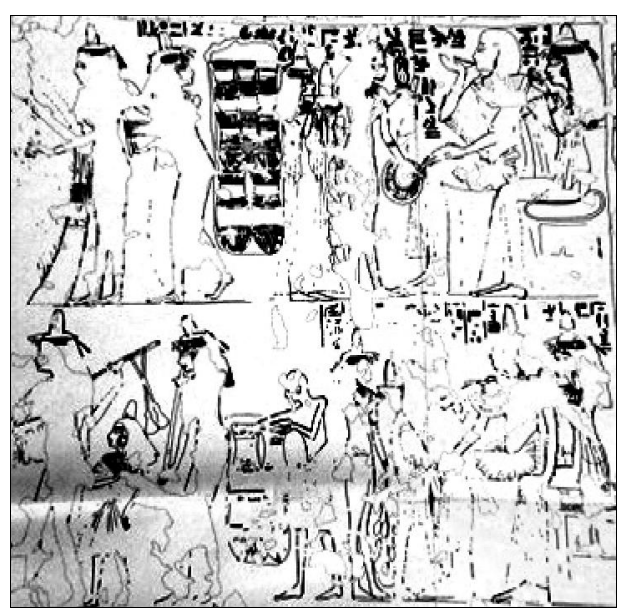

Fig. $13^{(1)}$

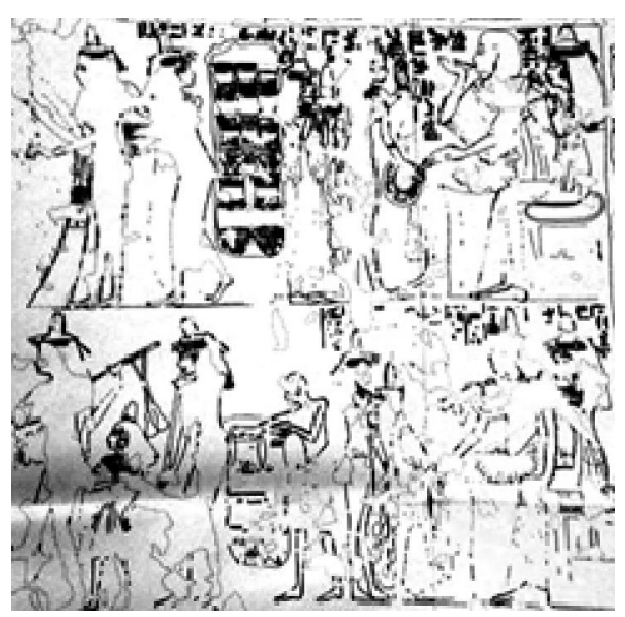

Fig.13

(1) Ibid., pl. XXXI scene 5.1.B,80 


\section{Bibliography}

- Abdel-Qader,M. Mohammed, Two Theban Tombs: Kyky and Bak-en-Amun. ASAE 59 (Cairo 1966).

- Allam, M. Mahdi, Joseph Lindon Smith, The Man and the Artist, Cairo, 1949.

- Baud, Marcelle, Etienne Drioton. Tombes thébaines: Nécropole de Dirâ' Abû 'nNága, Le tombeau de Roy, MIFAO57,1, Cairo, 1935.

- Baud,Marcel and Etienne Drioton, Le tombeau de Panehsy In: Georges Foucart, et al. Tombes thébaines: Nécropole de Dirâ' Abû'n-Naga: Le tombeau de Roÿ (tombeau no. 255); Le tombeau de Panehsy (tombeau no. 16); Le tombeau d'Amonmos (tombeau no. 19 ); Le tombeau d'Amon-am-anit (tombeau no. 277) (= MIFAO, 57, 2). Cairo, 1928-1935.

- Davies, Nina de Garis, Scenes from Some Theban Tombs (Nrs. 38, 66, 162, with Excerpts from 81) (= Private Tombs at Thebes, 4). Oxford: Griffith Institute, 1963.

- Davies, Norman de Garis, The Tomb of Nakht at Thebes, New York, MMA, 1917.

- Davies, Norman de Garis, Two Ramesside Tombs at Thebes: The Tomb of Antefoker, Vizier of Sesostris I and of His Wife Senet (No. 60),London: EES, 1920.

- Davies, Norman de Garis, A Peculiar Form of New Kingdom Lamp, JEA, Vol. 10, No. 1 (Apr., 1924).

- Davies, Norman de Garis, The Tomb of Nefer-hotep at Thebes, New York, 1933.

- Davies, Norman de Garis, The Tomb of the Two Sculptors at Thebes (= TTS, 4). New York, 1925.

- El-Shahawy, Abeer,The Funerary Art of Ancient Egypt, American UniversityC Press, 2005.

- Hawass, Zahi, Life In Paradise, The Noble Tombs of Thebes,American University CairoPress 2009.

- Henri, Wild, La tombe de Néfer-hotep (I) et Neb-néfer à Deir el-Médîna (No.6) et autres documents les concernant, MIFAO 103, Tome II, 1979.

- K.Wilkinson,Charles, Egyptian Wall Paintings, The Metropolitan Museum's Collection of Facsimiles, MMA New York, 1979.

- Manniche, Lisa, Lost Tombs, A Study of Certain Eighteenth Dynasty Monuments in the Theban Necropolis,New York,1988.

- Manniche, Lise. The Tomb of Nakht the Gardener, at Thebes, no. 161, as copied by Robert Hay, JEA 72, EES,London, 1986.

- Manniche, Lise, The Erotic Oboe In Ancient Egypt, Third International Meeting of the ICTM Study Group on Music Archaeology, Verlag für systematische Musikwissenschaft GmbH Bonn. 
- Nabil Zaki Marwan, Egyptian Agricultural Life in The New Kingdom, PhD Theses,Cairo University 1989,Department of Egyptology,1989.

- Saleh,Mohamed,Das Totenbuch in der Thebanischen Beamtengräbern des Neuen Reiches, Texte und Vignetten,Minze1984.

- Spencer, Patricia, Dance in Ancient Egypt, NEA, Vol. 66, No. 3, (Sep., 2003).

- Strudwick, Nigel. The Tombs of Amenhotep, Khnummose, and Amenmos at Thebes (Nrs. 294, 253, and 254) (= Griffith Institute Monographs, 1). Oxford; Griffith Institute, 1996.

\section{WEBSITES}

- http://www.osirisnet.net/tombes/nobles/anonyme175/photo/anonyme175 bs 38 893 detail_02.jpg.

- http://www.osirisnet.net/tombes/nobles/houy40/photo/houy40_cd_6477.jpg

- http://www.osirisnet.net/tombes/nobles/ramose/e_ramose55_p.2, C Copyright OsirisNet 2008

- http://www.osirisnet.net/tombes/nobles/userhat51/photo/userhat51_mr_17.jpg.

- http://www.segweb.ch/hari2/RH_02_2_09.jpg; http://www.osirisnet.net/tombes/nobles/roy/photo/roy_15.jpg

- http://www.osirisnet.net/tombes/nobles/kheru/photo/kherouef_oi_24.gif

- http://www.fitzmuseum.cam.ac.uk/tt99/tt254/images/71L.jpeg.

- http://www.griffith.ox.ac.uk/gri/4TT254.html (January 19, 2012) 